https://doi.org/10.30910/turkjans.678171
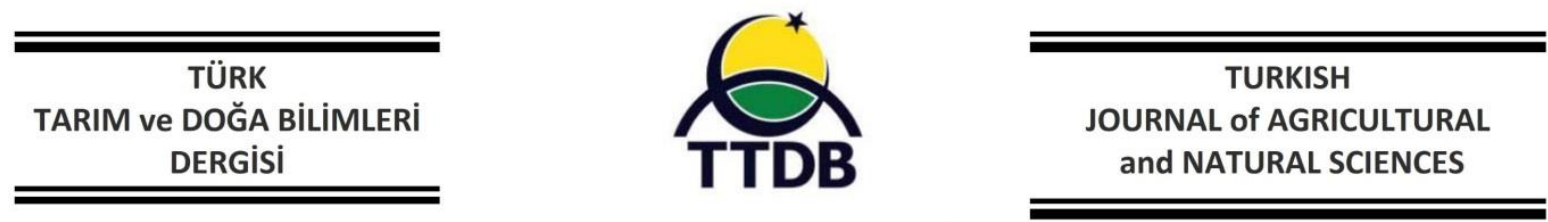

www.dergipark.gov.tr/turkjans

Research Article

\title{
Effects of Some Plant Growth Regulators and Phloroglucinol on Micropropagation of SP-2 (Prunus spinosa) Clonal Rootstock
}

\author{
Esra BULUNUZ PALAZ1* ${ }^{1 *}$ Remzi UĞUR ${ }^{1}$, Selver SARI ${ }^{2}$, Yeşim BÜYÜKÇINGIL ${ }^{1}$ \\ ${ }^{1}$ East Mediterranean Transitional Zone Agricultural Research of Institute, Kahramanmaras \\ ${ }^{2}$ Kahramanmaras Sutcu Imam University, Agriculture Faculty, Horticulture Department \\ *Corresponding Author: bulunuzesra@hotmail.com
}

Received: 21.01.2020 Revised in Received: 09.10.2020 Accepted: 14.10.2020

\begin{abstract}
This study was conducted in 2017 in order to work on the impacts of certain auxin, cytokine and phloroglucinol concentrations on propagation and rooting possibilities of SP-2 (Prunus spinosa) in vitro culture conditions. $1 / 2 \mathrm{MS}$ nutrient medium and different combinations of IBA (0.1-0.5-1.00 mg L-1 $)$, NAA (0.25 mg L-1), BA (0.5-1.00-2.00 mg L-1), Kinetin (0.5-1.00-2.00 mg L-1), Phloroglucinol (30-60-90-120 $\mathrm{mg} \mathrm{L}^{-1}$ ) and MSK-0 (normal $1 / 2$ MS without any hormone) were used as materials. It was observed at the end of the study that maximum shoot length per explant was at the MSK-7 combination $(25.11 \mathrm{~mm})$ and the highest plant multiplication was found as 6 for MSK-10 combinations per explant. In addition, the highest root length was $176.74 \mathrm{~mm}$ for the MSK-2 combinations while the highest root number was observed as 2 as per explant for MSK-5 combinations. As a result of this study, while control medium (MSK-0) remained below the distribution, the best rooting value was seen on the material, where MSK-2 and MSK-3 combinations was used. According to the result of this study, Phloroglucinol (PG) had a positive impact in vitro propagation of clonal rootstock candidates SP-2 (P. spinosa).
\end{abstract}

Key words: In vitro, micropropagation, plum, Prunus spinosa, rootstock

\section{Bazı Bitki büyüme Düzenleyicilerinin ve Phloroglucinol ‘ün SP-2 (Prunus spinosa) Klon Anacının Mikroçoğaltımına Olan Etkileri}

\section{Özet}

Bu çalışma, 2017 yılında bazı oksin, sitokinin ve phloroglucinol konsantrasyonlarının in vitro kültür koşullarında SP-2(Prunus spinosa) klon anacının rejenerasyon ve köklenme olasılıkları üzerine etkilerini araştırmak amacıyla yürütülmüştür. Materyal olarak $1 / 2 \mathrm{MS}$ besin ortamı ve farklı IBA kombinasyonları (0.1-0.5$\left.1.00 \mathrm{mg} \mathrm{L}^{-1}\right)$, NAA $\left(0.25 \mathrm{mg} \mathrm{L}^{-1}\right)$, BA (0.5-1.00-2.00 mg L-1), Kinetin (0.5-1.00-2.00 $\left.\mathrm{mg} \mathrm{L}^{-1}\right)$, Phloroglucinol (30-60$90-120 \mathrm{mg} \mathrm{L}^{-1}$ ) ve MSK-0 (herhangi bir hormon içermeyen normal $1 / 2 \mathrm{MS}$ ) kullanıldı. Çalışmanın sonunda eksplant başına maksimum sürgün uzunluğunun MSK-7 kombinasyonunda $(25.11 \mathrm{~mm})$ olduğu tespit edildi. Ayrıca, en yüksek kök uzunluğu MSK-2 ( 176.74 mm), en yüksek kök sayısı MSK-5 (2 adet/explant) kombinasyonlarında gözlendi. Bu çalışma sonucunda kontrol kombinasyonu (MSK-0) dağıımın alt kısımlarında kalırken, en iyi köklenme değeri MSK-2 ve MSK-3 kombinasyonlarının kullanıldı̆̆ı bitkilerde görülmüştür. Bu çalışmanın sonucuna göre, Phloroglucinol (PG), klonal anaç adayları SP-2'nin (Prunus spinosa) in vitro çoğaltımında olumlu bir etkiye sahip olduğu belirlenmiştir.

Anahtar kelimeler: In vitro, mikroüretim, erik, Prunus spinosa, anaç 


\section{Introduction}

Prunus spinosa is one of the plum variety. It grows in a more dwarf vigor as compared to other varieties and which is grown mostly in the natural environment of Turkey (Ozbek et al., 2014; Gulsoy and Balta, 2014). Not only 2-3 years old $P$. spinosa have thorns on their trees, but also they are prone to give many absorbers. Therefore, they are mostly planted as rootstocks as well as used for hybridization in plant breeding studies (Milosevic, 2006). Maas et al. (2014) reported that P.spinosa not only compatible rootstock for plum and prune but also for some apricot varieties as rootstock. Due to the following advantage, it is a candidate rootstock: does not give base shoots, can forward the nutrients to the grafted apricot very well, may be propagated with tissue culture and obtained through selection plant breeding (Ugur, 2017). It was showed that $P$. spinosa provides low vigor to dried apricot varieties ("Kabaasi", "Hasanbey" and "Hacihaliloglu") which are grafted on this mentioned rootstock. In comparison with Myrobolan 29C rootstock, 56\% more and with GF rootstock, 51\% more (Ugur and Paydas Kargi, 2017). In addition, SP-2 (P. spinosa) was found to be resistant to Meloidogyne incognita (race-1) and Meloidogyne javanica (race-1) with value $0.0 \pm 0.0$ according to egg-mass reaction scale (Gurkan et al., 2017).

It is reported that mostly Benzyladenin (BA), Benzylaminopurin (BAP) and Thidiazuron (TDZ) are used as cytokine hormones together with auxin hormones during the studies linked with the propagation of prunus rootstocks and varieties in tissue culture. These studies show that cytokine hormones give positive results (Sadeghi et al, 2015;
Zou, 2010; Nas et al., 2010; Petri and Scorza, 2009; Fotopoulos, Sotiropoulos, 2005; Andreu, Marin, 2005). In addition, indole-butyric acid (IBA), indoleacetic acid (IAA) and naphthalene-acetic acid (NAA) are commonly used as auxin forms (Silveira et al., 2002). Despite the fact Phloroglucinol (PG) is used for in vitro studies, its role for in vitro has not been highlighted until recently. It has been recently observed with studies that auxin and Phloroglucinol (PG) derivatives have synergetic impacts in vitro during micropropagation and rooting (Jaime et al., 2013). In addition, conducted researches have revealed that Phloroglucinol (PG) has antioxidant, antibacterial, antidepressant and anti-inflammatory phytochemical characteristics which will provide positive contribution to the plant health for in vitro conditions (Stein et al., 2012; Odabas and Cirak, 2011; Saddique et al., 2010; Kong et al., 2009; Crockett et al., 2008; Ahn et al., 2007; Athanasas et al., 2004; Winkelmann et al., 2003). It is possible to say that the rooting success of in vitro conditions may vary based on the concentrations of the hormones to be used as well as the accompanying material used (PerezToreno et al., 2000). According to the symptoms of the studies, it is also reported that the amount of the mineral material in a nutrient medium and the factors in its usage rates make a positive impact on the success of rooting accompanied with the contribution of the hormone concentrations (Vujovic et al., 2012; Dimassi-Theriou, 1995).

This study aims to investigate especially effect of Phloroglucinol on the regeneration and rooting possibilities of SP-2 ( $P$. spinosa) candidate rootstock.

\section{Materials and Methods}

Table 1. Combinations ( $\mathrm{mg} \mathrm{L}^{-1}$ ) of different hormones used in regeneration and rooting studies

\begin{tabular}{cccccc}
\hline $\begin{array}{c}\text { Name of } \\
\text { combination }\end{array}$ & IBA & NAA & BA & Kinetin & PG \\
\hline MSK-0 & - & - & - & - & - \\
MSK-1 & 0.1 & - & - & - & - \\
MSK-2 & 0.5 & - & - & - & - \\
MSK-3 & 1.0 & - & - & - & 30 \\
MSK-4 & - & - & - & - & 60 \\
MSK-5 & - & - & - & - & 90 \\
MSK-6 & - & - & - & - & 120 \\
MSK-7 & - & - & - & - & 60 \\
MSK-8 & - & - & - & 0.5 & 60 \\
MSK-9 & - & - & 1.0 & 1.0 & 60 \\
MSK-10 & - & 0.25 & 0.5 & 2.0 & 60 \\
MSK-11 & - & 0.25 & & \\
\hline
\end{tabular}

IBA: Indole butyric acid; NAA: Naphthalene acetic acid; BA: Benzyladenin; PG: Phloroglucinol; MSK: Code name of nutrient medium and hormone combination. 
Micro-shoot at a length of $10 \mathrm{~mm}$, which were taken from 8-week old grown plants in vitro conditions, have been used as an explant source in this study. Each explant was transferred to $1 / 2 \mathrm{MS}$ (Murashige, Skoog, 1962) nutrient medium with additional different concentrations of plant growth regulators (Table 1 ). $70 \mathrm{ml}$ within magentas at a size of $60 \times 100 \mathrm{~mm}$ were used and transfer completed at 25.08.2017. At the last phase, 6 g. $\mathrm{L}^{-1}$ amount of agar (for microbiology, Fluka ${ }^{\circledR}$ ) was added to nutrient medium and it was fixed to $\mathrm{pH}$ 5.8 and sterilized for a period of 15 minutes at $121^{\circ} \mathrm{C}$. After planting in petri dishes and the covers were closed. The mediums were exposed to 16 hours day ${ }^{-1}$ under fluorescent lamps of TLD 36

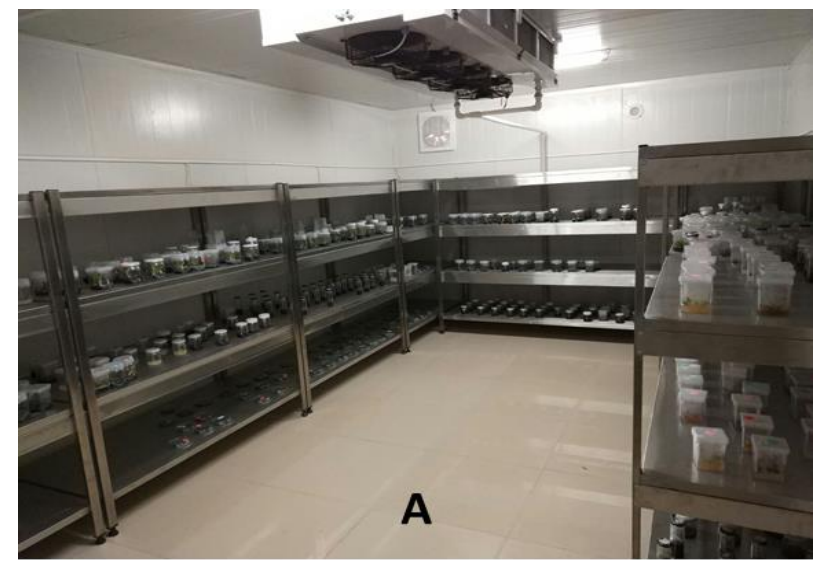

Figure 1. A. Climate chamber, B. Sterilization procedures.

\section{Results and Discussion}

Table 2 provides the regeneration status of SP-2 ( $P$. spinosa) rootstock candidates, which was taken for rooting in a concentrating of eleven different plant growth regulators. It was observed that the shoot lengths varied between $11.54 \mathrm{~mm}$ and $25.11 \mathrm{~mm}$ among the mediums, and the distinction was about $1 \%$ statistically. The longest shoot length was measured as $25.11 \mathrm{~mm}$ in MSK-7, and followed by MSK-1 and MSK-2 values as 22.23 $\mathrm{mm}$. Following three mediums were MSK-10, MSK8 and MSK- 9 combinations, which were statistically within the same group, respectively 21.01, 21.06 and $21.36 \mathrm{~mm}$. While the control media remained below the mean values, the shortest shoot length value was observed in the MSK-4 combination. Phloroglucinol (PG) applications made a positive contribution to the shoot length values based on result of the study. In addition, it was also detected that there was no antagonistic relationship on the combinations, which was formed by Phloroglucinol (PG) application with the cytokine groups (such as benzyl-adenine and kinetin). Also, the shoot length value, which was obtained from the above-
$\mathrm{W} / 84\left(45 \mu \mathrm{mol} \mathrm{m} \mathrm{s}^{-1}, 400-700 \mathrm{~nm}\right)$ at $\pm 21^{\circ} \mathrm{C}$ (Figure 1).

After about 91 days, the number and length of the companion shoots and the number and length of the roots per explant, which were obtained from the shoots, were calculated taking their arithmetical averages. In addition, their statistical analysis was made.

The study was established in a trial experiment layout of randomly selected parcels and as five explants on each petri and three petri dishes at each repetition. Analysis of variance (ANOVA) was applied to the obtained data, and the LSD test was used for multiple comparisons (Armitage, Herbert, 1996).

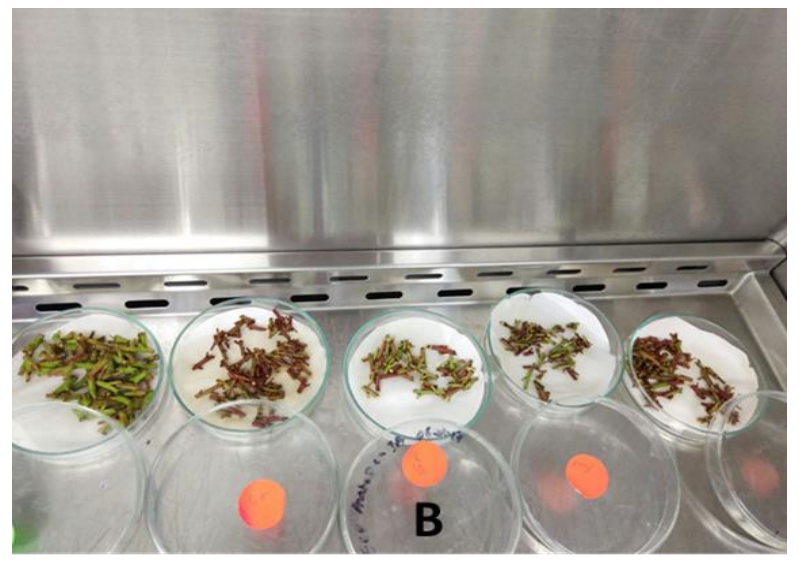

mentioned combinations, were within the same group of the values MSK-7 combination having the longest values statistically.

When the results obtained from this 91-day study was compared with the 30-day study of Fotopoulos and Sotiropoulos (2005), quite big differences have been observed. While the shoot length values in our study varied between 11.54 $\mathrm{mm}$ and $25.11 \mathrm{~mm}$ and lead to differences statistically, the shoot length values differed between $8.1 \mathrm{~mm}$ and $15.88 \mathrm{~mm}$. In addition, the plant growth regulator concentrations did not give rise to any difference in the shoot length values statistically. It is believed that such a case is caused by the fact that dual combinations were applied on a whole MS medium during the above-mentioned study, even if we applied 11 different plant growth regulator combinations in $1 / 2 \mathrm{MS}$ medium.

During the study conducted by Sadeghi et al. (2015) on vegetative propagation of half-dwarf Tetra $(P$. domestica) rootstock in vitro, three different doses of benzyl-adenine (BA) was used in two different medium. In this study conducted without using any other plant growth regulators, 
the shoot length values varied between 14.5 and $20.30 \mathrm{~mm}$ and such difference was statistically significant. In addition, the combinations applied during these mentioned two studies did not cause any increase in the number of companion plants. Nevertheless, the number of companion plants obtained from our study showed similarity with the results obtained by Fotopoulos and Sotiropoulos (2005); and Sadeghi et al. (2015). However, higher symptoms were obtained in our study as compared to the results of Petri and Scorza (2010). It is believed that such a case is result of Phloroglucinol (PG) derivative with other plant growth regulators combination. While the values of companion plant multiplication varied between 0 and 2 pieces, the MSK-10 and MSK-11 hormone combined-media got the values 6 and 4.88 respectively. When the impact of the same applicant on companion plant multiplication, these differences were statistically important. It was also determined that combinations other than these two combinations were included in the same group with very close values between each other.

Table 2. Proliferation and multiplication of SP (Prunus spinosa)

\begin{tabular}{ccc}
\hline Combinations & Shoot length $(\mathbf{m m})$ & Number of shoots \\
\hline MSK-0 & $18.66 \pm 0.67^{\mathrm{d}}$ & $1.75 \pm 0.75^{\mathrm{c}}$ \\
MSK-1 & $22.23 \pm 0.14^{\mathrm{ab}}$ & $2.12 \pm 0.29^{\mathrm{c}}$ \\
MSK-2 & $22.23 \pm 0.95^{\mathrm{ab}}$ & $1.66 \pm 0.58^{\mathrm{c}}$ \\
MSK-3 & $15.72 \pm 1.80^{\mathrm{e}}$ & $1.83 \pm 0.80^{\mathrm{c}}$ \\
MSK-4 & $11.54 \pm 0.45^{\mathrm{f}}$ & $1.80 \pm 0.80^{\mathrm{c}}$ \\
MSK-5 & $24.55 \pm 0.10^{\mathrm{ab}}$ & $1.95 \pm 0.33^{\mathrm{c}}$ \\
MSK-6 & $18.74 \pm 1.40^{\mathrm{d}}$ & $1.67 \pm 0.12^{\mathrm{c}}$ \\
MSK-7 & $25.11 \pm 2.82^{\mathrm{a}}$ & $1.78 \pm 0.68^{\mathrm{c}}$ \\
MSK-8 & $21.06 \pm 2.66^{\mathrm{cd}}$ & $1.83 \pm 0.36^{\mathrm{c}}$ \\
MSK-9 & $21.36 \pm 0.64^{\mathrm{c}}$ & $2.41 \pm 0.19^{\mathrm{c}}$ \\
MSK-10 & $21.01 \pm 0.37^{\mathrm{cd}}$ & $6.00 \pm 0.47^{\mathrm{a}}$ \\
MSK-11 & $18.85 \pm 1.95^{\mathrm{d}}$ & $4.88 \pm 0.43^{\mathrm{b}}$ \\
\hline LSD 0.05 & $\mathbf{2 . 4 7 ^ { * * }}$ & $\mathbf{0 . 8 8 ^ { * * }}$ \\
\hline
\end{tabular}

$\mathrm{F}^{* *} \mathrm{P} \leq 0.01$ and $\mathrm{F}^{*} \mathrm{P} \leq 0.05$ shows significance level. Distinct letters in the first and second columns indicate significant differences according to LSD's test $(P \leq 0.05)$.
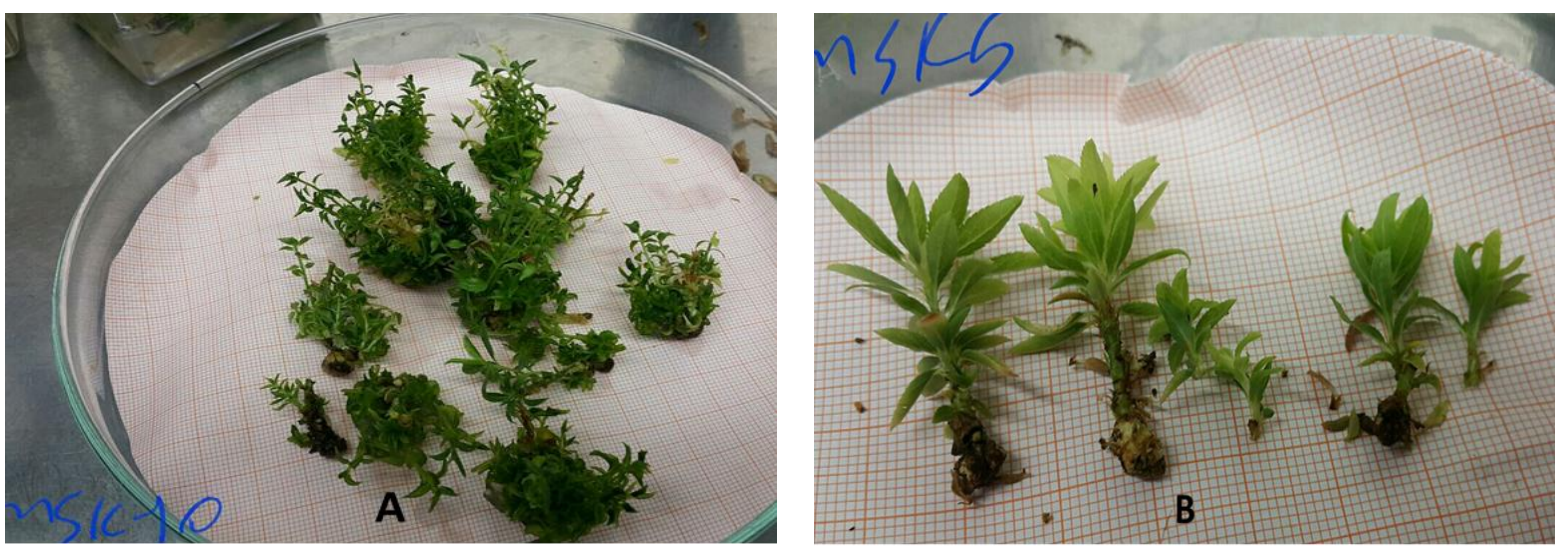

Figure 2. A. Companion plants on explants; B. Separated companion plants.

It stands out that the last two hormone combinations were the most complex ones used in the study. It can be said that the decreasing amounts of benzyl-adenine (BA) and increasing amounts of kinetin made a negative impact on the formation of companion plants. In other words, a number of companion plants is higher when benzyl-adenine (BA) concentration is higher than kinetin concentration. In addition, it was expected that increasing Phloroglucinol (PG) concentration in the amounts of $30 \mathrm{mg} \mathrm{L}^{-1}, 60 \mathrm{mg} \mathrm{L}^{-1}, 90 \mathrm{mg} \mathrm{L}^{-1}$,
$120 \mathrm{mg} \mathrm{L}^{-1}$ would increase the number of companion plants. However, $60 \mathrm{mg} \mathrm{\textrm {L } ^ { - 1 }}$ concentration application showed better impacts in case of other hormones usage. These results indicate that better results may be taken if Phloroglucinol (PG) derivative form proper concentrations with auxin and cytokine hormones.

Rooting status of SP-2 ( $P$. spinosa) rootstock candidates, which were rooted in eleven different plant growth regulator concentrations, are given in Table 3. It was observed that the root length values 
varied between 0 and $176.74 \mathrm{~mm}$ among different media, and the differences were statistically important at the level of $1 \%$. The highest root length values were seen as 176.74 and $174.55 \mathrm{~mm}$, respectively in nutrient media MSK-2 and MSK-3 combined with hormones remain statistically within the same group. In addition, it may also be said that a significant root development has occurred with a length of $145.50 \mathrm{~mm}$ in nutrient medium MSK-5. Least root development (number root) was observed in combinations MSK-4, MSK-7, MSK-10 and MSK-11.

Table 3. Rooting status of SP (P. spinosa)

\begin{tabular}{ccc}
\hline Combinations & Root length $(\mathbf{m m})$ & Number of Roots \\
\hline MSK-0 & $80.50 \pm 0.50^{\mathrm{f}}$ & $1.33 \pm 0.33^{\mathrm{abc}}$ \\
MSK-1 & $101.68 \pm 1.69^{\mathrm{d}}$ & $1.50 \pm 0.50^{\mathrm{ab}}$ \\
MSK-2 & $176.74 \pm 2.00^{\mathrm{a}}$ & $1.38 \pm 0.35^{\mathrm{ab}}$ \\
MSK-3 & $174.55 \pm 0.20^{\mathrm{a}}$ & $1.50 \pm 0.00^{\mathrm{ab}}$ \\
MSK-4 & $91.33 \pm 3.21^{\mathrm{e}}$ & $0.33 \pm 0.00^{\mathrm{d}}$ \\
MSK-5 & $145.50 \pm 0.50^{\mathrm{b}}$ & $2.00^{\mathrm{a}} \pm 1.00^{\mathrm{a}}$ \\
MSK-6 & $119.33 \pm 3.06^{\mathrm{c}}$ & $1.50 \pm 0.50^{\mathrm{ab}}$ \\
MSK-7 & $90.66 \pm 2.52^{\mathrm{e}}$ & $0.50 \pm 0.00^{\mathrm{cd}}$ \\
MSK-8 & $100.00 \pm 2.65^{\mathrm{d}}$ & $1.16 \pm 0.00^{\mathrm{a}-\mathrm{d}}$ \\
MSK-9 & $88.00 \pm 2.00^{\mathrm{e}}$ & $1.00 \pm 0.00^{\mathrm{bcd}}$ \\
MSK-10 & $13.66 \pm 1.53^{\mathrm{g}}$ & $0.33 \pm 0.00^{\mathrm{d}}$ \\
MSK-11 & $12.66 \pm 1.53^{\mathrm{g}}$ & $0.33 \pm 0.00^{\mathrm{d}}$ \\
\hline LSD $_{0.05}$ & $\mathbf{3 . 4}$ & $\mathbf{0 . 8 4 ^ { * * }}$
\end{tabular}

$\mathrm{F}^{* *} \mathrm{P} \leq 0.01$ and $\mathrm{F}^{*} \mathrm{P} \leq 0.05$ shows significance level. Distinct letters in the first and second columns indicate significant differences according to LSD's test $(P \leq 0.05)$.

According to result of this study, the increasing doses of indole-butyric acid as 0.1, 05 and $1.00 \mathrm{mg} \mathrm{L}^{-1}$ improved on root development. Phloroglucinol (PG) derivative could not make expected impact, unlike indole-butyric acid (IBA) application. It was observed that the positive effects of multiple hormone combinations remained limited in the root development of SP-2 $(P$. spinosa) rootstock candidate. Besides, only indole-butyric acid (IBA) application would be sufficient.
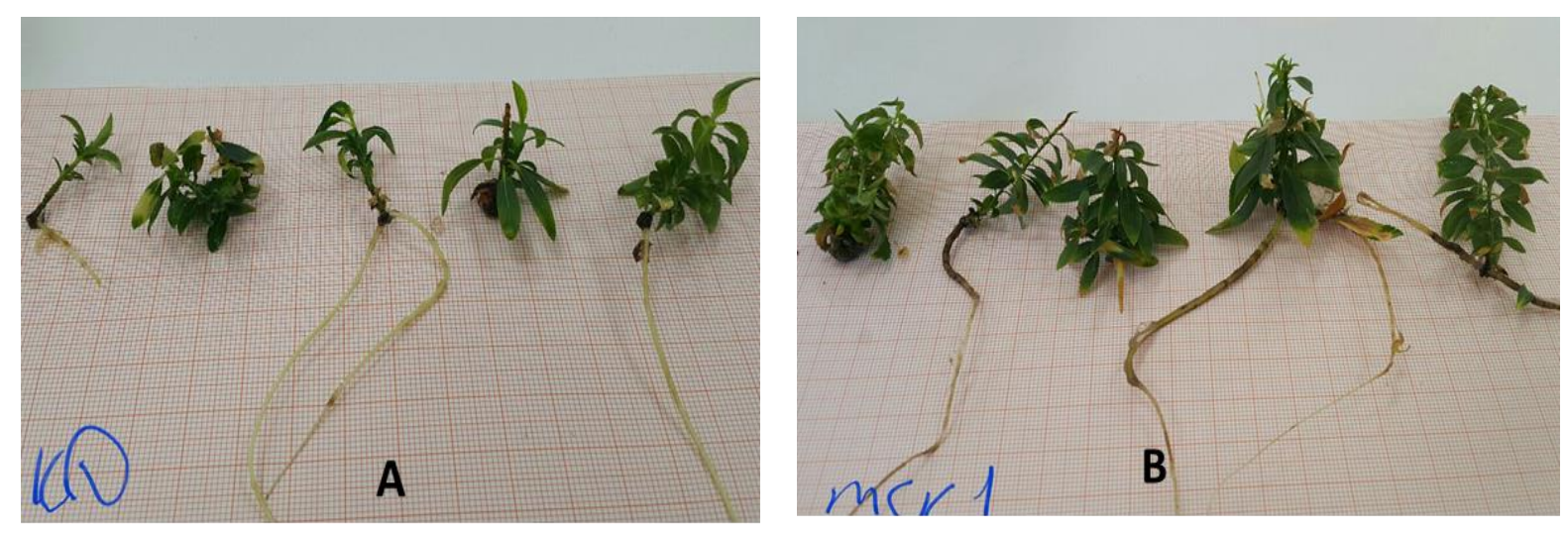

Figure 3. A. Rooted small plants (MSK-0); B. Rooted small plants (MSK-1).

The best root numbers were seen in MSK-5, MSK-1, MSK-3 and MSK-6 hormone concentrated nutrient media. Moreover, no statistically difference occurred in terms of root number values varied between 2.00 and 1.50 per explant. These results are parallel with the root length values. However, application of Phloroglucinol (PG) derivate at an amount of $60 \mathrm{mg} \mathrm{L}^{-1}$ gave better results than the other hormone concentration applications. And also, it encouraged more branching on the roots.

Root development results shows that indole-butyric acid (IBA) application supplemented with hormone concentrations made positive impact on root development. It is also remarkable that Phloroglucinol (PG) derivative gave positive result in root formation. Similarly, Ugur and Palaz (2018) reported that MSK-control medium in vitro positive effect on propagation of SP-2 ( $P$. spinosa) 
rootstock candidate. The number of the companion plants in the above-mentioned study was not at the expected level. And more, there was no statistical relationship between the hormone applications. These two data proved the necessity of an alternative study in connection with in vitro production of the mentioned rootstock candidate. Likewise, it was observed in this study that Phloroglucinol (PG) derivative makes a statistically important impact on the formation of the companion plants. The range of root length development in MSK-1 with the lowest indolebutyric acid (IBA) concentration took place in the middle, and MSK-3 with the highest concentration could not provide the highest root length value. Because the highest value was achieved from MSK2 combination. It can be said that there is no relationship between the increasing indole-butyric acid (IBA) doses and the root length values. Furthermore, similar results were taken as a result of another study conducted on the same rootstock candidate by Ugur and Palaz (2018). Sadeghi et al. (2015) conducted an in vitro study and used Tetra rootstock belonging to the $P$. domestica plum species, which is a close relative of SP-2 ( $P$. spinosa) rootstock candidate. They applied IBA concentrations in three different nutrient media. Although the increasing doses of IBA in three different nutrient media, they observed reduction in the root length values. And, they determined that significant changes of hormone doses occurred statistically in terms of the number of roots similar to the results of our study. However, during the study conducted with a different hybrid rootstock PR204/84 (P. persica $\times$ P. amygdalus) by Fotopoulos and Sotiropoulos in 2005, it was observed that average root length values increased in parallel with the increasing IBA doses. It is supposed that such a distinction in different rootstocks may be caused by arising from certain inherent factors. It is remarkable that results obtained from our study conducted on SP-2 ( $P$. spinosa) as well as the study conducted by Sadeghi et al. (2015) on Tetra ( $P$. domestica), as these rootstocks are close relatives. It is a good result in commercial terms that Phloroglucinol (PG) derivative makes a positive impact on companion plant numbers at a statistically important level.
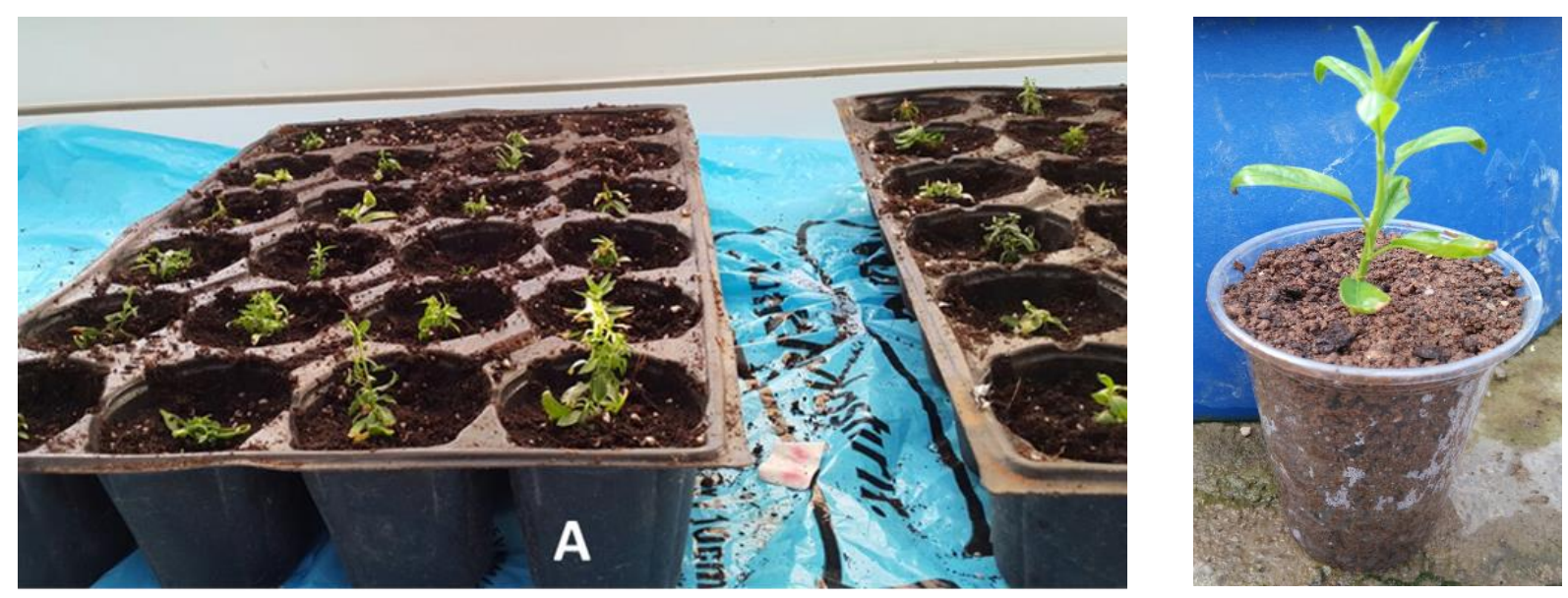

Figure 4. Acclimatization of rooted plants in viol and pot.

\section{Conclusion}

In this study in vitro rooting of the SP-2 ( $P$. spinosa) rootstock candidate, ten different hormone concentrations were used. MSK-10 and MSK-11 medium including benzyl-adenine (BA), kinetin, indole-butyric acid (IBA), naphthaleneacetic acid (NAA) and Phloroglucinol (PG) gave positive results in formation of companion plants among hormone concentrations. In addition, while increasing doses usage of Phloroglucinol (PG) improved the shoot length, while it was not effective in the formation of the companion plants alone. The application of Phloroglucinol (PG) alone made a positive impact on rooting. Decreases were determined in root and shoot development in $1 / 2$
MS application. Combinations including benzyladenine (BA), kinetin, indole-butyric acid (IBA), naphthalene-acetic acid (NAA) and Phloroglucinol (PG) give a positive result commercially in regeneration stage. And, usage of Phloroglucinol (PG) alone may make positive affection during rooting stage. However, it must always be kept in mind that different concentrations may give better results.

Çıkar Conflict of Interest Statement: The manuscript's authors declare that, they do not have any conflict of interest. 
Researchers' Contribution Rate

Statement Summary: The authors declare that, they have contributed equally to the manuscript.

\section{References}

Ahn, G., Kim, K., Cha, S., Song, C., Lee, J., Heo, M., Yeo, I., Lee, N., Jee, Y., Kim, J., Heu, M., Jeon, Y. 2007. Antioxidant activities of phlorotannins purified from Ecklonia cava on free radical scavenging using ESR and $\mathrm{H}_{2} \mathrm{O}_{2}$-mediated DNA damage. European Food Research Technology, 226: 71-79. DOI 10.1007/s00217-006-0510-y.

Andreu, P., Marin, J. A. 2005. In vitro culture establishment and multiplication of the Prunus rootstock 'Adesoto101' (Prunus institia L.) as affected by the type of propagation of the donor plant and by the culture medium composition. Scientia Horticulturae, 106: 258-267. DOi 10.1016/j.scienta.2005.03.008.

Armitage, P., Herbert, D. A. 1996. Advances in Biometry. New York, USA, p. 268-275.

Athanasas, K., Magiatis, P., Fokialakis, N., Skaltsounis, A.L., Pratsinis, H., Kletsas, D. 2004. Hyperjovinols A and B: two new phloroglucinol derivatives from Hypericum jovis with antioxidant activity in cell cultures. Journal of Natural Products, 67: 973-977. DOi 10.1021/np034051w.

Crockett, S., Wenzig, E., Kunert, O., Bauer, R. 2008. Anti-inflammatory phloroglucinol derivatives from Hypericum empetrifolium. Phytochemistry Letters, 1: 37-43. DOi 10.1016/j.phytol.2007.12.003.

Dimassi-Theriou, K. 1995. In vitro Rooting of Rootstock GF-677 (Prunus amygdalus $\times P$. persica) as influenced by mineral concentration of the nutrient medium and type of culture-tube sealing material. Journal of Horticultural Science, 70: 105108.

DOi

10.1080/14620316.1995.11515279.

Fotopoulos, S., Sotiropoulos, T. E. 2005. In vitro Propagation of the PR 204/84 (Prunus persica $\times P$. amygdalus) Rootstock: Axillary shoot production and rhizogenesis. New Zealand Journal of Crop and Horticultural Science, 33: 75-79. DOi 10.1080/01140671.2005.9514333.

Gurkan, B., Ugur, R., Gurkan, T. 2017. Reactions of Meloidogyne incognita race 1 and Meloidogyne javanica race 1 against some plum rootstock. Turkish Journal of Agriculture and Natural Sciences, 5: 64-70.
Jaime, A., Silva, T., Dobranszki, J., Ross, S. 2013. Phloroglucinol in plant tissue culture. In Vitro Cellular and Developmental Biology Plant, 49: 1-16. DOI 10.1007/s11627-0139491-2.

Kong, C., Kim, J., Yoon, N., Kim, S. 2009. Induction of apoptosis by phloroglucinol derivative from Ecklonia cava. Food Chemical Toxicology, 47: 1653-1658. DOi 10.1016/j.fct.2009.04.013.

Maas, F. M., Balkhoven-Baart, J., Van der Steeg, P. A. H. 2014. Selection of Prunus spinosa as a dwarfing rootstock for high density plum orchards. Acta Horticulturae, 1058: 507516.

DOi 10.17660/ActaHortic.2014.1058.63.

Milosevic, T. 2006. Effects of interstock on seasonal changes in microelement concentrations in apricot leaf. Acta Horticulturae, 701: 719722.

DOi

10.17660/ActaHortic.2006.701.128.

Murashige T., Skoog, F. 1962. A revised medium for rapid growth and bioassays with tobacco tissue cultures. Physiology of Plant, 15: 473497.

Nas, M. N., Bolek, Y., Sevgin, N. 2010. The effect of explant and cytokine type on regeneration of Prunus microcarpa. Scientia Horticulturae, 126: 88-94. DOi 10.1016/j.scienta.2010.06.012.

Odabas, M. S., Cirak, C. 2011. Hypericum. Medical Aromatic Plant Science Biotechnology, 5: 1107.

Ozbek, B., Kayım, M., Elekçioğlu, i. H. 2014. Evaluation of resistance for root-knot nematodes (Meloidogyne incognita and Meloidogyne javanica [Tylenchida: Meloidogynidae]) of some Prunus rootstocks grown in vitro conditions. Journal of Agricultural Faculty of Uludag University, 28(2): 27-35.

Perez-Tornero, O., Egea, J., Vanoostende, A., Burgos, L. 2000. Assessment of factors affecting adventitious shoot regeneration from in vitro cultured leaves of apricot. Plant Science, 158: 61-70. DOI 10.1016/S0168-9452(00)00303-4.

Petri, C., Scorza, R. 2009. Factors affecting adventitious regeneration from in vitro leaf explant of 'Improved French' plum, the most important dried plum cultivar in the USA. Annals of Applied Biology, 156: 79-89. Doi:10.1111/j.1744-7348.2009.00364.x.

Saddique, Z., Naeem, I., Maimoona, A. 2010. A review of the antibacterial activity of Hypericum perforatum L. Journal of 
Ethnopharmacology, 131: 511-521. DOi 10.1016/j.jep.2010.07.034.

Sadeghi, F., Yadollahi, A., Jafarkhani Kermani, M., Eftekhari, M. 2015. Optimizing culture media for in vitro proliferation and rooting of Tetra (Prunus empyrean 3) rootstock. Journal of Genetic Engineering and Biotechnology, 13: 19-23. Doi.10.1016/j.jgeb.2014.12.006.

Silveira, C., Fortes, G., Fachinello, J., Rodrigues, A., Citadin, I., Quezada, A., Silva, J. 2002. In vitro multiplication of prunus rootstocks under low concentration and different auxin. Revista Brasilera Fruticulturae, 24: 608-610. DOI 10.1590/S010029452002000300006.

Stein, A. C., Viana, A. F., Muller, L. G., Nunes, J. M., Stolz, E. D., do Rego, J. C., Costentin, J., Von Poser, G. L., Ratesa, S. M. K. 2012. Uliginosin B, Phloroglucinol derivative from Hypericum polyanthemum: A promising new molecular pattern for the development of antidepressant drugs. Behavioral Brain Research, 228: 66-73. DOI 10.1016/j.bbr.2011.11.031.

Ugur, R. 2017. Investigation of Rootstock Characteristics of Some Wild Plum Species Obtained by Clone Selection from Kahramanmaras Flora. Doctoral Dissertation. Cukurova University, Department of Horticulture, p. 324.

Ugur, R., Paydas Kargi, S. 2017. Investigation of growing situations of apricot varieties grafted on clonal rootstock candidate some wild plum genotypes obtained by selection. Turkish Journal of Natural and Agricultural Science, 5: 64-70.

Ugur, R., Altun, O., Ozatar, H.O., Aras, S., Erayman, M., Paydas, Kargi, S. 2016. Investigation of rooting possibilities of different Prunus domestica hardwood cuttings obtained by selection. Journal of Ataturk Central Horticultural Research Institute, 45(1): 325328.

Winkelmann, K., San, M., Kypriotakis, Z., Skaltsa, H., Bosilij, B., Heilmann, J. 2003. Antibacterial and cytotoxic activity of prenylated bicyclic acylphloroglucinol derivatives from Hypericum amblycalyx. Zeitschrift für Naturforsch Journal of Bioscience, 58: 527-532.

Vujovic, Ruzic, Dj, Cerovic, R. 2012. In vitro shoot multiplication as influenced by repeated subculturing of shoots of contemporary fruit rootstocks. Hort. Science, 39: 101-107.

Zou, Y. N. 2010. Micropropagation of Chinese plum (Prunus salicina L.) using mature stem segments. Notulae Botanicae Horti Agrobotanici Cluj, 38(3): 214-218. DOi $10.15835 /$ nbha3834614. 